\title{
Lignocellulosic biomass for bioenergy beyond intensive cropland and forests
}

Authors: Koenraad Van Meerbeek ${ }^{\mathrm{a}, \mathrm{b}^{*}}$, Bart Muys $^{\mathrm{a}}$ and Martin Hermy ${ }^{\mathrm{a}}$

\section{Affiliations:}

${ }^{a}$ Department of Earth and Environmental Sciences, University of Leuven, Celestijnenlaan 200E, 3001 Leuven, Belgium.

${ }^{\mathrm{b}}$ Department of Bioscience, Aarhus University, Ny Munkegade 116, 8000 Aarhus, Denmark

*Corresponding author

E-mail address: koenraad.vanmeerbeek@kuleuven.com 


\section{Abstract}

Pathways towards decarbonization of society to limit global warming well below $2^{\circ} \mathrm{C}$ heavily rely on bioenergy. The predicted increase in biomass demand raises concerns about the sustainability of large-scale bioenergy deployment. To investigate the diversification of biomass supply this synthesis gives an overview of the underused biomass potential of landscapes beyond croplands and forests: gardens, roadsides, conservation areas, sport fields etc. In Western Europe, their annual biomass production ranges from 2.0 to $9.2 \mathrm{Mg}$ dry matter per hectare, while intensive agriculture can produce $12.0-20.4 \mathrm{Mg}$ dry matter per year under the same climatic conditions. However, the net energy balance (energy output minus energy inputs) of landscape bioenergy has the potential to be higher than that of some of the current bioenergy systems (ranges between 4.9-28.4 and 11.0-68.8 GJ per ha respectively). These landscape elements have in common that biomass is removed for other purposes than bioenergy production and they already provide indispensable ecosystem services to society. The scattered availability of this resource in space and time, however, limits a general implementation of landscape bioenergy. The deployment of landscape biomass is promising in regions where the management is organized, and where it could be combined with the energetic valorization of other organic waste streams. In a case study, the landscape biomass potential of an urbanized region in Western Europe is quantified and the feasibility of integrating landscape biomass together with other waste streams in the bioenergy chain is further explored. Anaerobic digestion of $1087 \mathrm{Gg}$ landscape biomass (fresh weight) together with other organic waste streams could potentially generate 12.7 PJ gross per year, or $20 \%$ of the current renewable energy production in the study region. Results of this study show that landscape biomass has the potential to diversify the current biomass portfolio and can effectively contribute to the decarbonization of society.

\section{Keywords}

Anaerobic digestion, conservation area, landscape biomass, lawn, road verge, urban area

\section{Abbreviations}

LIHD: Low-Input High-Diversity

LILD: Low-Input Low-Diversity

HIHD: High-Input High-Diversity

HILD: High-Input Low-Diversity 
IAS: Invasive alien species

EU: European Union

IFFB: Integrated generation of solid Fuel and Biogas from Biomass

ILUC: Indirect Land-Use Change

NEB: Net Energy Balance

SD: Standard deviation 


\section{Introduction}

\subsection{On the sustainability of large-scale bioenergy deployment}

At the 2015 UNFCCC conference in Paris, parties agreed to keep climate warming well below $2^{\circ} \mathrm{C}$ relative to pre-industrial levels and further try to limit the increase in temperature to $1.5^{\circ} \mathrm{C}$. The dual temperature limits in the agreement arise from scientific evidence that the legally binding $2{ }^{\circ} \mathrm{C}$ boundary already corresponds to greatly increased risks of catastrophic tipping points with a negative impact on society, economy and environment [1-3]. However, the Intergovernmental Panel on Climate Change (IPCC) warns that without additional, far-reaching policies and mitigation measures, greenhouse gas (GHG) emissions will increase drastically, reaching concentration levels between 750 and more than 1300 parts per million (ppm) $\mathrm{CO}_{2-}$ equivalents by 2100 [2]. This is far more than the $450 \mathrm{ppm}$ concentration level, consistent with a likely chance to achieve the Paris temperature goal.

In the roadmap towards a decarbonized global economy, energy from renewable sources plays a large role to achieve short and long term climate goals [4]. In spite of its significant potential to mitigate climate change, renewable sources provided only $13.7 \%$ of the world's primary energy supply in 2015 (78.3 EJ [5]). Bioenergy, i.e. the renewable energy produced from organic matter like woody biomass, agricultural crops and organic waste, represents the largest share in this category worldwide (77\% or $60 \mathrm{EJ}$ [5]) and will continue to play a critical role for mitigation in the future [6]. The removal of $\mathrm{CO}_{2}$ via bioenergy combined with carbon capture and storage techniques seems indispensable to limit global warming to below $1.5^{\circ} \mathrm{C}[2,7]$. A review about future contribution of biomass to global energy supply attributes the largest share to energy crops (22-1,272 EJ), exceeding that of forestry (60-230 EJ), organic waste (12-120 EJ), agricultural (10-66 EJ) and forestry residues (3-35 EJ) [8]. One of the foundations of many bioenergy models, however, is that through land-use intensification, agricultural land will become available for the production of energy crops. However, this assumption is increasingly questioned [8]. With the growing population and increasing biomass demands for bioenergy, food and fiber production, claims on agricultural land are high, all while yield increases are slowing down and the degradation of agricultural land and water scarcity are growing worldwide problems [9]. The competition of large-scale expansion of energy crops with production of food or livestock feed for fertile lands induces indirect land-use change and associated increases in GHG emissions [10,11]. Hence, concerns are raised that the expanding cultivation of bioenergy crops fails to achieve its sustainability objectives [12]. The growing 
disjunction between global supply and demand for agricultural land has been called 'a perfect storm in the making' [9].

Proposed solutions to achieve the climate goals without adverse effects on food security and the environment include substitution with bioenergy from forest biomass. Increasing deployment of forest bioenergy is motivated by the claim of carbon neutrality, because the emitted carbon is recaptured in the biomass of growing trees. However, recent evidence refutes the assumption that bioenergy from forest biomass is always carbon neutral [13-15]. Although sustainable forest management will result in a decrease of GHG emissions in the long term, fossil fuel substitution could take decades to pay back the carbon debt created by the decline in forest carbon stocks $[13,14]$. To avoid these negative effects of bioenergy production, it is clear that biomass production cannot be accomplished only on intensive croplands or in forests. The supply of biomass for bioenergy needs to be diversified.

\subsection{Biomass beyond cropland and forests}

Looking for alternatives for bioenergy crops grown in High-Input Low-Diversity (HILD) systems with high anthropogenic inputs and specifically managed for low biodiversity, Tilman et al. [16] explored the biomass potential of non-woody systems beyond intensive cropland areas. Opposite to HILD systems, they proposed Low-Input High-Diversity (LIHD) systems as a promising alternative source of biomass for the production of bioenergy. This review explores the bioenergy potential in the rest of the 'anthropogenic input - biodiversity continuum' shaped by the level of biodiversity and the amount of human inputs (fertilizers, irrigation, pesticides, and management effort) applied in the system (relative to HILD systems, Fig. 1). First, an overview is given of biomass availability in the landscape categories that are commonly left out in biomass potential assessments [e.g. 17, 18-20]. Biomass originating from landscape management is until now barely valorized. It is often even regarded as waste to which extra processing costs are connected, because of its abundant availability in summer and limited disposal options [21-23]. However, promising pathways to valorize this lignocellulosic biomass exist and are discussed here. Then, the applicability of landscape bioenergy in urban areas is illustrated in a case study, which explores the biomass-for-bioenergy resource potential present in the landscape in an urbanized region in Western Europe. The case study takes into account the energy expenditure related to all steps in the valorization process and reports both the gross and net energy potential. The focus of the study is on systems with herbaceous biomass: open habitats in conservation areas, herbaceous roadsides, lawns in gardens and parks, sport fields, 
etc. Forests are not included in this study, because forest carbon sequestration is assumed to be the better option for climate mitigation than additional harvest of forest biomass or forest residues for forest bioenergy [14]. In addition to the combination of a review and an illustrative case study, this research is innovative because it considers the landscape categories as they are, instead of estimating the biomass potential assuming an unrealistic conversion of the land use to high-yielding bioenergy crops [e.g. 24, 25].

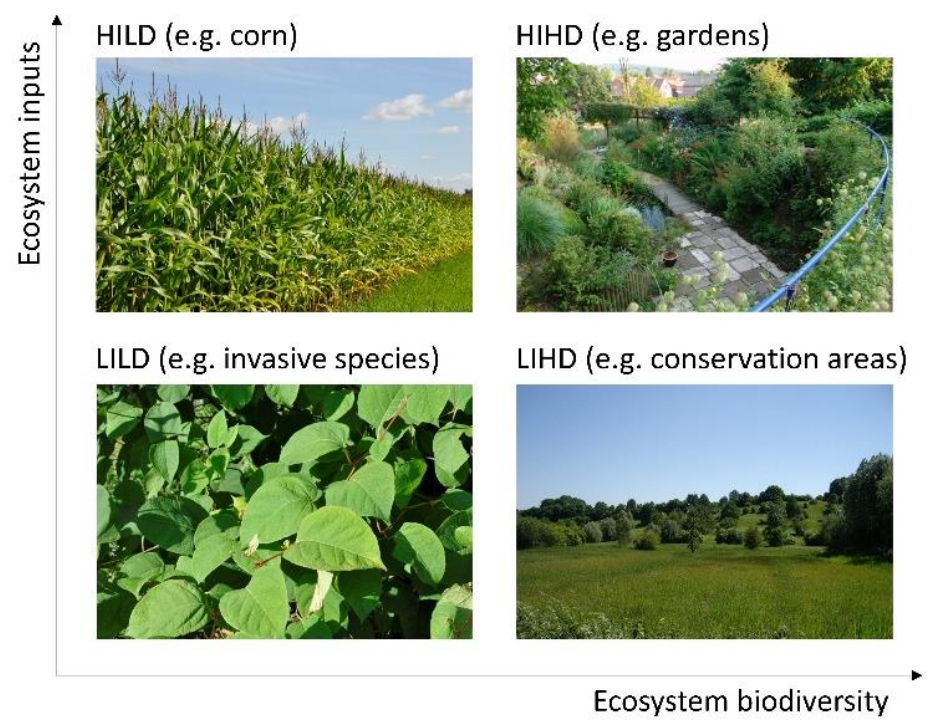

Fig. 1 The four major landscape categories in the human input - biodiversity continuum. LILD: low-input low-diversity, LIHD: low-input high-diversity, HILD: high-input low-diversity and HIHD: highinput high-diversity [Pictures: HILD, LILD, LIHD: K. Van Meerbeek, HIHD: M. Hermy]. Inputs and biodiversity values are relative to intensive agricultural systems (HILD).

\section{Biomass potential in the landscape}

\subsection{Low-Input High-Diversity systems}

The term Low-Input High-Diversity systems is used to describe (plant) species-rich systems in which biomass grows without (or with limited) human inputs aiming at increased production, like fertilizers or pesticides. North American research about LIHD biofuels focused on grasslands with native species sown on abandoned and degraded agricultural land $[16,26]$. In Europe, the biomass resource potential of mainly conservation areas and roadsides has been explored in this category [e.g. 27]. Society does not manage these systems for biomass production, but still the maintenance produces a lot of lignocellulosic biomass annually. Conservation areas could be mown to maintain open semi-natural biodiverse ecosystems like grasslands, heathlands and marshes [28, 29]. Forage quality of conservation biomass is often too low to be used for livestock production, because of the ban of fertilizers in conservation 
areas and conservation goals often imply late harvest dates [30-32]. Bioenergy recovery from LIHD systems could thus incentivize the protection of biodiversity [21]. Preventing road encroachment and maintaining visibility are the main goals of roadside management, but they also are also important as refugia and green corridors for species in urban areas [27, 33]. Pollution like heavy metals from vehicle emissions and littering hinder the further use of roadside clippings. The extra expenses to process roadside and conservation clippings are often avoided by leaving the biomass in the field [21-23, 34]. Van Meerbeek et al. [35] already reviewed the annual biomass production in open (non-forest) plant communities in European conservation areas. Biomass production ranged from less than $1 \mathrm{Mg}$ dry matter (DM) ha ${ }^{-1} \mathrm{yr}^{-1}$ in inland dunes to almost $7 \mathrm{Mg} \mathrm{DM} \mathrm{ha} \mathrm{yr}^{-1}$ in the richest grassland systems. For roadsides, Meyer et al. [36] found an annual biomass production in Denmark of $2.04( \pm 0.80$ standard deviation, $\mathrm{SD}$ ) $\mathrm{Mg} \mathrm{DM} \mathrm{ha}^{-1}$ (2 cuts per year), which is much less than found in Germany (5.68 $\pm 3.90[37])$ or Belgium (7.66 \pm 1.65 [27]).

Although roadside and conservation biomass have already been suggested to be a sustainable bioenergy feedstock [38], they are commonly omitted in assessments of biomass resource potential [e.g. 39, 40, 41]. Therefore, until recently, little was known about their spatial extent. In Wales, the management of semi-natural areas produces 1.05 Tg DM of biomass annually and could yield $212 \mathrm{Gg}$ of liquid biofuel through the Fischer-Tropsch process [21]. The European Natura 2000 network of conservation areas covers almost $20 \%$ of the terrestrial area of the European Union (78 million hectares) and is the largest conservation network in the world [42]. 7.5 million hectares of non-forest plant communities within Natura 2000 produce $17.9 \mathrm{Tg} \mathrm{DM}$ of biomass each year. Paved roads in Europe (EU28) span around 5 million km [43], more than in the USA or China. Although no data for Europe exist, roadsides consequently cover a very large area. The surface area of grass roadsides in Denmark has been estimated between 15,745 and 25,178 ha for 34,983 km of roads [36]. In Flanders (northern urbanized region of Belgium), there are $62,940 \mathrm{~km}$ of roads with a total of 13,800 ha grass roadsides [27]. This is in the same order of magnitude as the total cover of open habitats in conservation areas in the same region (17,260 ha). The average width of roadsides with herbaceous vegetation (sum of both sides) in Flanders varies from $3.04( \pm 2.48) \mathrm{m}$ for municipal roads to $5.49( \pm 5.96) \mathrm{m}$ for regional roads and $14.83( \pm 12.29) \mathrm{m}$ for motorways [27].

LIHD biofuels minimize the competition with food production, because the biomass is grown on degraded and infertile land [44]. While the first generation biofuels are often net carbon 
sources [45, 46], certainly when land-use change is taken into account [10, 47], LIHD systems sequester more carbon than is released during production and use of the fuel [16]. In their paper in Science in 2006, Tilman et al. [16] promoted LIHD biofuels as having a higher net energy balance (NEB, sum of the energy outputs of the biofuel minus the sum of the fossil energy inputs) compared with food-based biofuels. The biomass yield per hectare is lower (Fig. 2), but this is more than compensated by the lower energy inputs of the system. Until now, few studies have followed their example and explored the NEB of LIHD biofuel systems (Fig. 3). Meyer et al. [36] studied the feasibility of utilizing roadside biomass for biogas production in Denmark. Van Meerbeek et al. [27] investigated the integration of roadside and conservation biomass into the existing bioenergy chain. Energy inputs in these biofuels systems were indeed lower than used during the production process of most current HILD biofuels. However, because of the much lower output, the NEB was still lower than observed in the highly productive HILD biofuel systems. Only in terms of NEB ratio (energy output/input), LIHD biofuels are more competitive than HILD systems. This can be an important feature in the future.

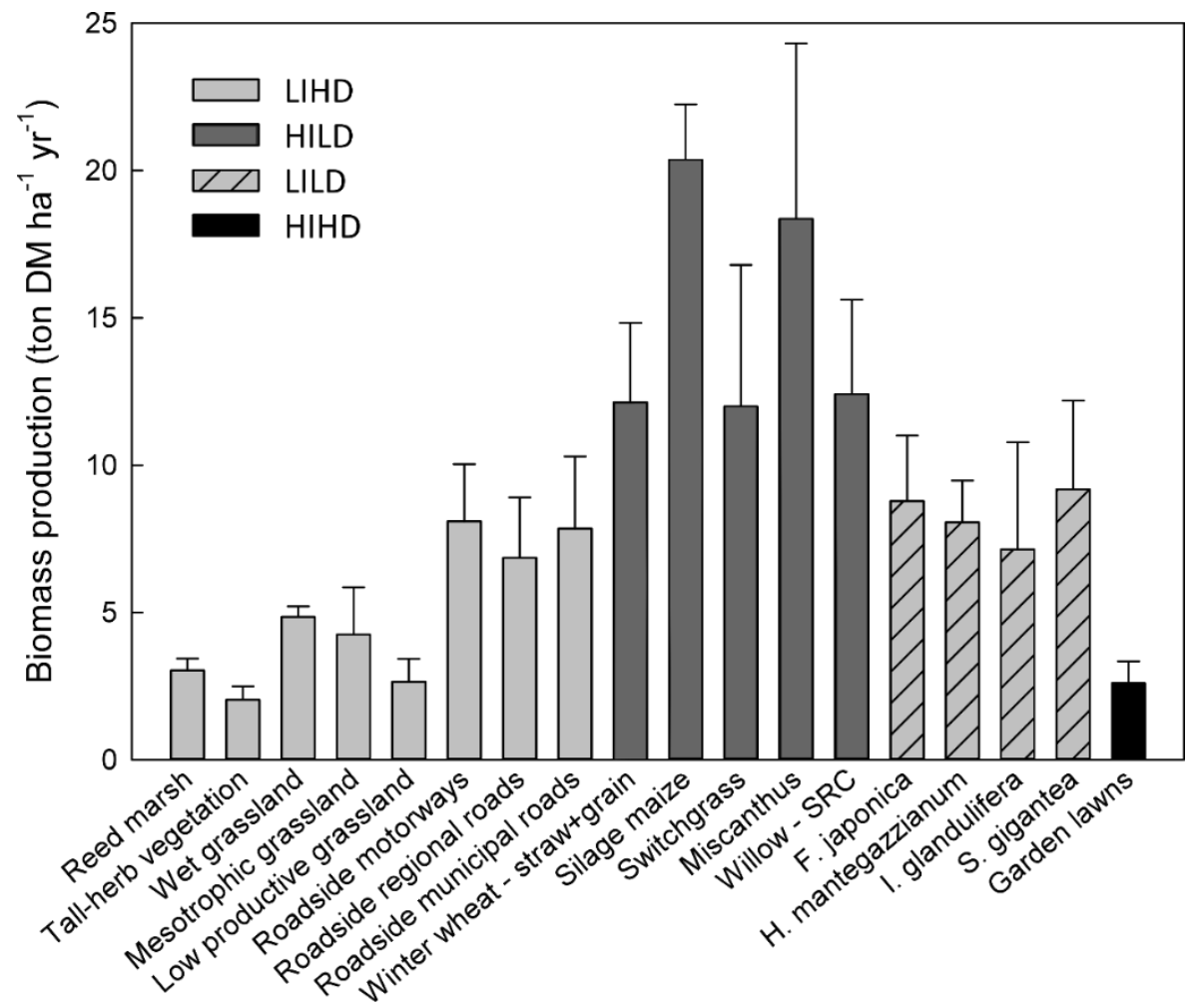

Fig. 2 Biomass production (Mg dry matter ha-1 $\mathrm{yr}^{-1} \pm \mathrm{SD}$ ) in different landscape categories. In order to make a valid comparison between categories, data from the same region (W. Europe) are shown. SRC: Short rotation coppice, invasive exotic plants species: F. japonica: Fallopia japonica, H. mantegazzianum: Hercleum mantegazzianum, I. glandulifera: Impatiens glandulifera, S. gigantea: Solidago gigantea. Data with references are included in Table A1. 


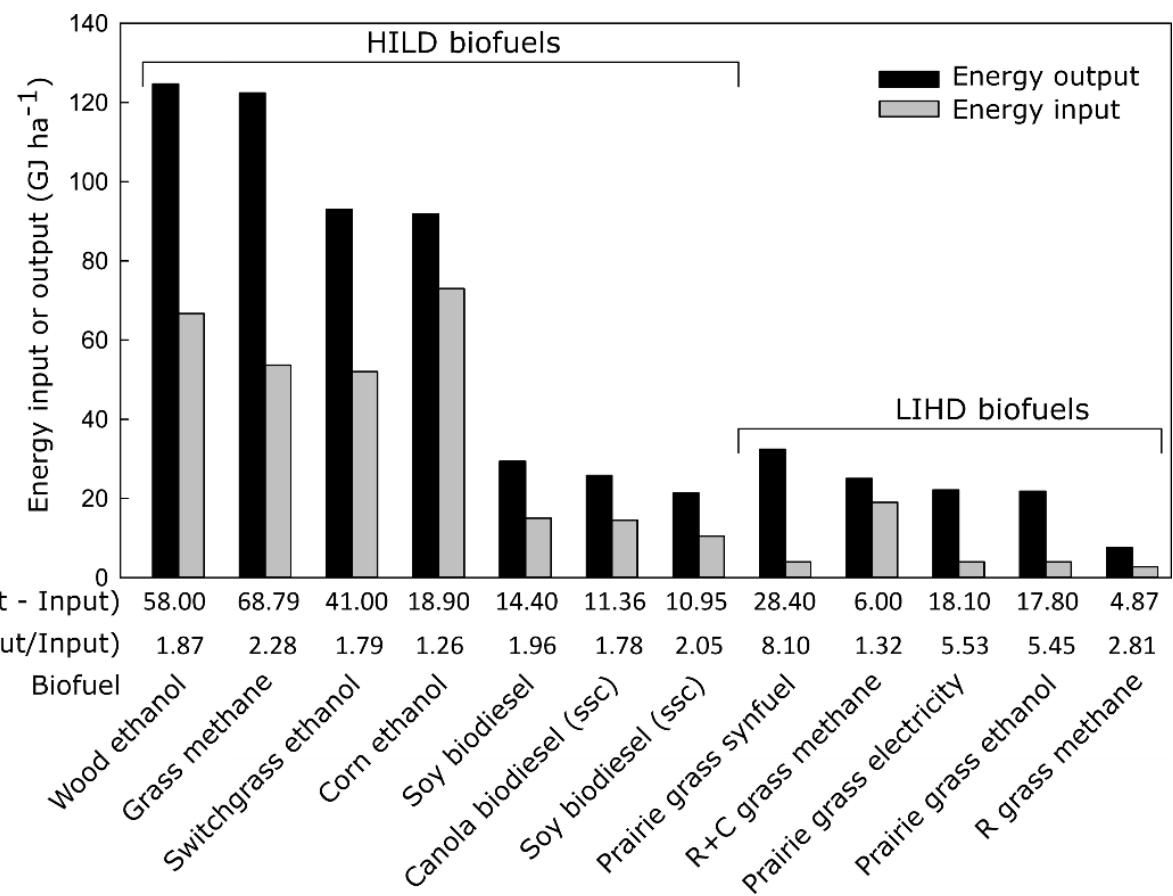

Fig. 3 Net energy balance (NEB) and NEB ratio of different HILD and LIHD biofuels (GJ ha-1). Data and references are included in Appendix A. ssc: small-scale, R: roadside, C: conservation. The NEB takes into account all inputs related to the whole process (from harvest to energetic valorization).

\subsection{Low-Input Low-Diversity systems}

Low-Input Low-Diversity systems (LILD) score low on both axes in the biodiversity-ecosystem input continuum (Fig. 1). A common example of LILD are ecosystems that are invaded by invasive alien plant species (IAS, [48]). Despite the lack of inputs and without any agronomic optimization, successful invading plant species often have a large biomass production (Fig. 2), thereby outcompeting the native vegetation. Several hypotheses on the mechanisms that are responsible for the success and high productivity of non-indigenous invaders in their introduced range have been raised in the literature [e.g. 49, 50]. In the Czech republic, Japanese knotweed (Fallopia japonica) has a biomass production of $9.06( \pm 3.96 \mathrm{SD})$ ton $\mathrm{DM} \mathrm{ha}^{-1} \mathrm{yr}^{-1}$, while the annual yield of Fallopia $x$ bohemica (hybrid between $F$. japonica and $F$. sachalinensis) is more than double with $19.78( \pm 5.37)$ ton $\mathrm{DM} \mathrm{ha}^{-1}$ [51]. Kudzu (Pueraria montana), a vine native in Eastern Asia and introduced in the US, has most of its biomass stored belowground: 13.6 ( \pm 0.60) $\mathrm{Mg}$ DM compared to 5.00 ( \pm 0.70$) \mathrm{Mg}$ DM aboveground [52]. Van Meerbeek et al. [48] studied the annual biomass and bioenergy potential of four herbaceous invasive species in Belgium: Japanese knotweed $(8.61 \pm 2.21 \mathrm{Mg} \mathrm{DM} \mathrm{ha-1})$, Giant hogweed (Heracleum 
mantegazzianum; $6.04 \pm 0.89$ ), Himalayan balsam (Impatiens glandulifera; $5.78 \pm 3.24$ ) and Late goldenrod (Solidago gigantea; $8.64 \pm 2.96$ ).

Numbers of IAS are rapidly growing worldwide with major ecological [53] and economic [54] consequences. Although efforts are increasing, few eradication programs have been successful so far [55]. The use of these species as a bioenergy feedstock or for other purposes can reduce the cost of active management and can help to restore invaded areas. Most bioenergy research considering invasive species, however, focus on the potential risk of invasion associated with the cultivation of new bioenergy crops $[56,57]$. Although the high biomass production of IAS makes them an attractive bioenergy feedstock, bioenergy potential of present invasive species remains little exploited [58]. Jakubowksi et al. [59] calculated the bioenergy benefits of the ecological restoration of 200,000 ha of wetlands in Wisconsin invaded by Reed canary grass (Phalaris arundinacea). With a peak standing biomass between 6.81 and $14.08 \mathrm{Mg} \mathrm{DM}$, the restoration could provide $2,406 \mathrm{Gg}$ of bioenergy feedstock annually, with the potential energy

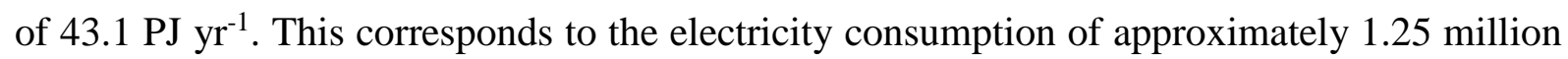
households. Nackley et al. [60] performed the same exercise for the invasive woody Russian olive (Elaeagnus angustifolia) in the Columbia River Basin. Clearing 367,000 ha of invaded ecosystems would yield 6,233 to $21,266 \mathrm{Gg}$ of woody biomass. Removing all the biomass could provide a sustainable biomass supply for a local combined heat and power bioenergy facility for several decades. Possible application of IAS biomass goes beyond bioenergy production, like the production of biochemicals [61].

Deployment of invasive species biomass is however not without risks, as it provides new dispersal opportunities created by transportation, storage and processing of the biomass. Successful bioenergy deployment could further be a reason for the bioenergy industry to lobby for the expansion of these crops to new areas [62]. Strict rules and a legal framework must ensure that biomass utilization does not get in the way of the control or eradication of these species [63]. Further research and screening of new bioenergy supply chains using invasive species biomass is needed to exclude or minimize the dispersal risk.

\subsection{High-Input High-Diversity systems}

In the third category of the continuum, domestic gardens, parks and other urban green are usually intensively managed in order to maintain a high (plant) diversity for esthetic reasons. 
In addition to the high cultivated plant diversity [64, 65], gardens and parks often provide valuable habitat for other species groups, like birds [66] or invertebrate species [67]. However, because of the preference of alien plant species above native ones (e.g. $70 \%$ of the UK garden flora is not native [64]) and the excessive use of pesticides and fertilizers, garden biodiversity consists in general of common species, rather than specialists [68]. Robbins \& Birkenholtz [69] compared the use of chemical pesticides in residential areas with that on agricultural land in the USA and found application rates in gardens to be almost three times higher ( 9.18 vs $3.24 \mathrm{~kg}$ of active ingredients $\left.\mathrm{ha}^{-1} \mathrm{yr}^{-1}\right)$. A fertilization rate of $97.6( \pm 88.3 \mathrm{SD}) \mathrm{kg} \mathrm{N} \mathrm{ha}^{-1} \mathrm{yr}^{-1}$ is observed in residential lawns in Baltimore (USA) [70]. In Flanders, Dewaelheyns et al. [71] noted an excessive use of fertilizers and soil conditioners (on average $700 \mathrm{~kg}$ bulk ha $\mathrm{hr}^{-1} \mathrm{yr}^{-1}$ ), leading to $\mathrm{pH}$ and phosphorus levels well over the growth optimum.

Although small-scaled and scattered, gardens can still make up a large area in total: In Flanders (Belgium), 9\% of the total area is covered by gardens $[72,73]$ and in the UK, gardens cover 432,924 ha, which is almost $2 \%$ of the total land area [74]. Especially in the urban landscape, the share of gardens can be considerable: Gardens occupy 16\% of Stockholm metropolitan area [75], around one fourth of the area of five UK cities [76], and 36\% of the urban area in Dunedin, New Zealand [77]. In Franklin County (Ohio, USA), garden lawns occupy around $23 \%$ of the total land cover [69]. The amount of harvested grass clippings in lawns varies between 1.44

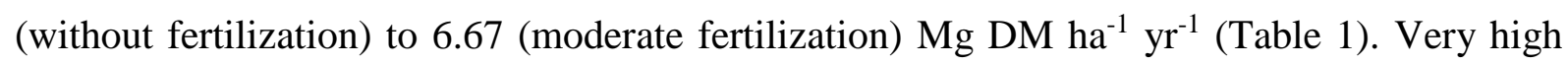
fertilization rates beyond the range for optimal plant growth are besides the frequent mowing regime a possible explanation for the lower biomass production of lawns compared to the other considered landscape categories ([71], and see Fig. 2). Still, given the large area, clippings from garden lawns and urban green areas are a potential large source of biomass. Almost one third of the metropolitan area of Albuquerque (7,650 ha) is covered by turfgrass ( $85 \%$ garden lawns, $8.3 \%$ parks and $6.7 \%$ golf courses) and could provide an annual supply of 4,575 Mg DM of grass clippings for bioenergy production [78]. Also taking into account fallen leaves and tree prunings, the green space in the city of Woodward (Oklahoma, USA) yields 8.0 to $19.0 \mathrm{Mg}$ DM of biomass $\mathrm{ha}^{-1}$ or between 3,750 and $6,100 \mathrm{Mg}$ in total each year [79]. Scaling up these results, around 164 million Mg DM of biomass could be collected in urban green areas in the USA [79]. Milesi et al. [80] estimated that lawns cover between 127,950 and $199,650 \mathrm{~km}^{2}$ of land in continental USA. 
Table 1 Annual yield of grass clippings from lawns (Mg DM ha-1 $\left.\mathrm{yr}^{-1} \pm \mathrm{SD}\right)$. Pp: Poa pratensis, Cd: Cynodon dactylon, Fa: Festuca arundinacea, Lp: Lolium perenne

\begin{tabular}{|c|c|c|c|c|c|}
\hline Location & Species & $\begin{array}{l}\text { Grass clippings } \\
\left(\mathrm{Mg} \mathrm{DM} \mathrm{ha}^{-1} \mathrm{yr}^{-1}\right)\end{array}$ & $\begin{array}{c}\text { Nr of cuts during } \\
\text { the season }\end{array}$ & $\begin{array}{c}\text { Fertilization } \\
\left(\mathrm{ha}^{-1} \mathrm{yr}^{-1}\right)\end{array}$ & Ref \\
\hline Woodward (OK, USA) & $\mathrm{Cd}$ & $4.00 \pm 0.63^{\square}$ & 10 to 12 & $\begin{array}{c}4838 \mathrm{~kg} \mathrm{NPK} \\
\text { bulk* }^{*}\end{array}$ & [79] \\
\hline Albuquerque (NM, USA) & $\mathrm{Pp}, \mathrm{Cd}, \mathrm{Fa}$ & 6.76 & 26 & $18-68 \mathrm{~kg} \mathrm{~N}^{\ddagger}$ & [78] \\
\hline \multirow[t]{6}{*}{ West Lafayette (IN, USA) } & $\mathrm{Pp}$ & $4.64 \pm 0.48$ & 23 to 26 & $196 \mathrm{~kg} \mathrm{~N}^{*}$ & {$[81]$} \\
\hline & $\mathrm{Pp}$ & $1.82 \pm 0.06$ & 23 to 26 & No fertilization* & \\
\hline & $\mathrm{Lp}$ & $3.48 \pm 0.32$ & 23 to 26 & $196 \mathrm{~kg} \mathrm{~N}^{*}$ & \\
\hline & Lp & $1.44 \pm 0.29$ & 23 to 26 & No fertilization* & \\
\hline & $\mathrm{Fa}$ & $4.96 \pm 0.20$ & 23 to 26 & $196 \mathrm{~kg} \mathrm{~N}^{*}$ & \\
\hline & $\mathrm{Fa}$ & $2.24 \pm 0.53$ & 23 to 26 & No fertilization* & \\
\hline Fort Collins (CO, USA) & $\mathrm{Pp}$ & $4.70 \pm 0.0 .87$ & 28 & $185 \mathrm{~kg} \mathrm{~N}^{*}$ & [82] \\
\hline Belgium & Not specified & $2.60 \pm 0.74^{\dagger}$ & 20 & 700 kg bulk $\ddagger$ & [71] \\
\hline
\end{tabular}

\section{From landscape biomass to bioenergy}

A wide array of biochemical, thermochemical and mechanical conversion technologies are available to process biomass into bioenergy. The physical and chemical properties of the biomass, the availability of knowledge, the presence of conversion facilities and spatiotemporal availability of the biomass impose restrictions on the possibilities [12]. Unlike agricultural land, the considered systems are often small-scaled and spatially dispersed. Together with the high moisture content and the large volume of the biomass, this increases transportation costs and limits the competitiveness of the bioenergy deployment. Hence, technologies that require large-scale energy conversion facilities are not recommended for energy generation from landscape biomass $[83,84]$. Combustion and anaerobic digestion can be done decentralized $[85,86]$ and both technologies were proven to be suitable for conversion of lignocellulosic landscape biomass with a heterogeneous composition [87-90]. Woody biomass has a high dry matter content and low detrimental element concentrations and is therefore a good feedstock for combustion. The high moisture content of herbaceous biomass does, however, negatively affect the energy balance of combustion [91]. In addition, high concentrations of nitrogen, potassium, chlorine and sulfur lead to problems such as deposit formation, ash melting, corrosion and increased emissions [88, 92]. Late harvest dates, as is common in conservation areas, improve biofuel quality [83], but to fire wet, herbaceous biomass pre-treatment will often be necessary. Postharvest leaching by precipitation and drying in the field are possible options [90], but are weather dependent and increase the number of 
handling steps. Hence, wet, herbaceous biomass is better processed through anaerobic digestion, avoiding high pre-treatment costs [91].

Systems that are regularly mown (e.g. sport fields and lawns in gardens or parks) have easily digestible biomass. The conversion efficiency of digestion of biomass with late harvest dates and thus higher contents of lignin (e.g. roadside and conservation biomass) is generally low (10-30\% [89]). There are several possibilities to improve the digestibility of lignocellulosic feedstock. Co-digestion with nitrogen-rich feedstock, like sewage sludge, kitchen waste or manure, adjusts the high $\mathrm{C}: \mathrm{N}$ ratio and increases biogas production [93]. Physical, thermal or chemical pre-treatments can also be applied to break down the long polymers and improve digestibility [e.g. 94, 95]. The presence of litter and dirt in roadside biomass can cause problems during digestion, because of damage to the rotators and sediment formation. In this case, specialized dry anaerobic digestion technologies without a mixing device inside the digester or with a vertical design to prevent sediment layers can offer a solution $[65,96]$.

A technical procedure called 'Integrated generation of solid Fuel and Biogas from Biomass' (IFBB) was specifically designed to overcome the low energy yield and abovementioned quality limitations of herbaceous landscape biomass [97]. IFBB results in the production of solid fuel and biogas and improves both biofuel quality and energy yield. The IFBB procedure converts the biomass in a press cake with reduced element concentrations and a press fluid that can be used in anaerobic digestion. The technique is already tested and validated with biomass originating from LIHD (grass clippings from conservation areas and roadsides), LILD (invasive species biomass), HIHD (green cut from gardens and parks) and HILD systems (grass clippings from sport fields and bioenergy crops) [92, 98-102]. Thermochemical processing of the biomass prior to energy conversion is a second strategy to overcome biomass quality limitations. Pyrolysis and torrefaction (also called mild pyrolysis) both increase energy density and hydrophobicity, and reduce moisture content and biodegradability [103]. Biomass is heated between $200-300{ }^{\circ} \mathrm{C}$ (torrefaction) or between $350-800{ }^{\circ} \mathrm{C}$ (pyrolysis) in anaerobic conditions, and converted to torrefied biomass or biochar and oil respectively [104-106]. When combined with hydrothermal conditioning, element concentrations and ash content can also be reduced [103]. Another advantage is that after decentralized thermochemical pretreatment, the resulting fuel can be transported and used centrally as feedstock for gasification or combustion, thereby lowering handling, transportation and storage cost. Torrefaction and pyrolysis have already been found to overcome logistic and quality constraints of energy generation of landscape biomass [103, 107, 108]. 


\section{Biomass potential of urbanized regions: a case study}

Bioenergy deployment of landscape biomass is especially promising in regions where the management is well organized, and where processing facilities are widespread [38]. In urbanized regions, there is the additional advantage that landscape biomass could be integrated with the energetic valorization of other organic waste streams like organic kitchen waste, sewage sludge or waste of the food industry. In this part, the regional landscape biomass potential in Flanders, the northern administrative region of Belgium (Western Europe) is assessed and compared to the current production of bioenergy crops on HILD land. With a population of almost 6.5 million (in 2017) and covering an area of only 13,522 km², Flanders has an average population density of 481 habitants $\mathrm{km}^{-2}$ and is one of the most densely populated regions in the world [109]. Flanders serves as a model for urbanized regions in a temperate climate and is in this regard highly relevant for a future in an increasingly urbanized world. Today, already more than half of the world's population is living in urban areas and by 2050 , this is projected to increase to $66 \%$ [110]. This trend will result in a drastic expansion of urbanized land [111].

Flanders was further selected because the region is facing a serious challenge to meet its EU 2020 renewable energy targets and ensure a sustainable future. According to the European Renewable Energy Directive, $13 \%$ of the gross energy consumption in this region should come from renewable sources by 2020 [112]. In 2016, this share was only $6.4 \%$ (or 17,905 GWh [113]) and continuing the trend of the past 10 years, Flanders will not reach its targets in 2020. The share of biofuels in the transportation sector was only 5.9\% (or $3248 \mathrm{GWh}$ ) in 2016, while the European Commission has set the minimum level at 10\% in 2020 [114]. Great efforts should be made to accelerate the transition to a green economy. Although the ambition for bioenergy is recently scaled back by the Flemish government, bioenergy will still play an important role in reaching the predefined goals [115]. Another reason to choose Flanders as study area is the availability of high-resolution and good quality data on land use and land cover. An overview of the data, references and methodology to quantify the surface area and biomass production of the considered landscape categories is added as appendix B. 

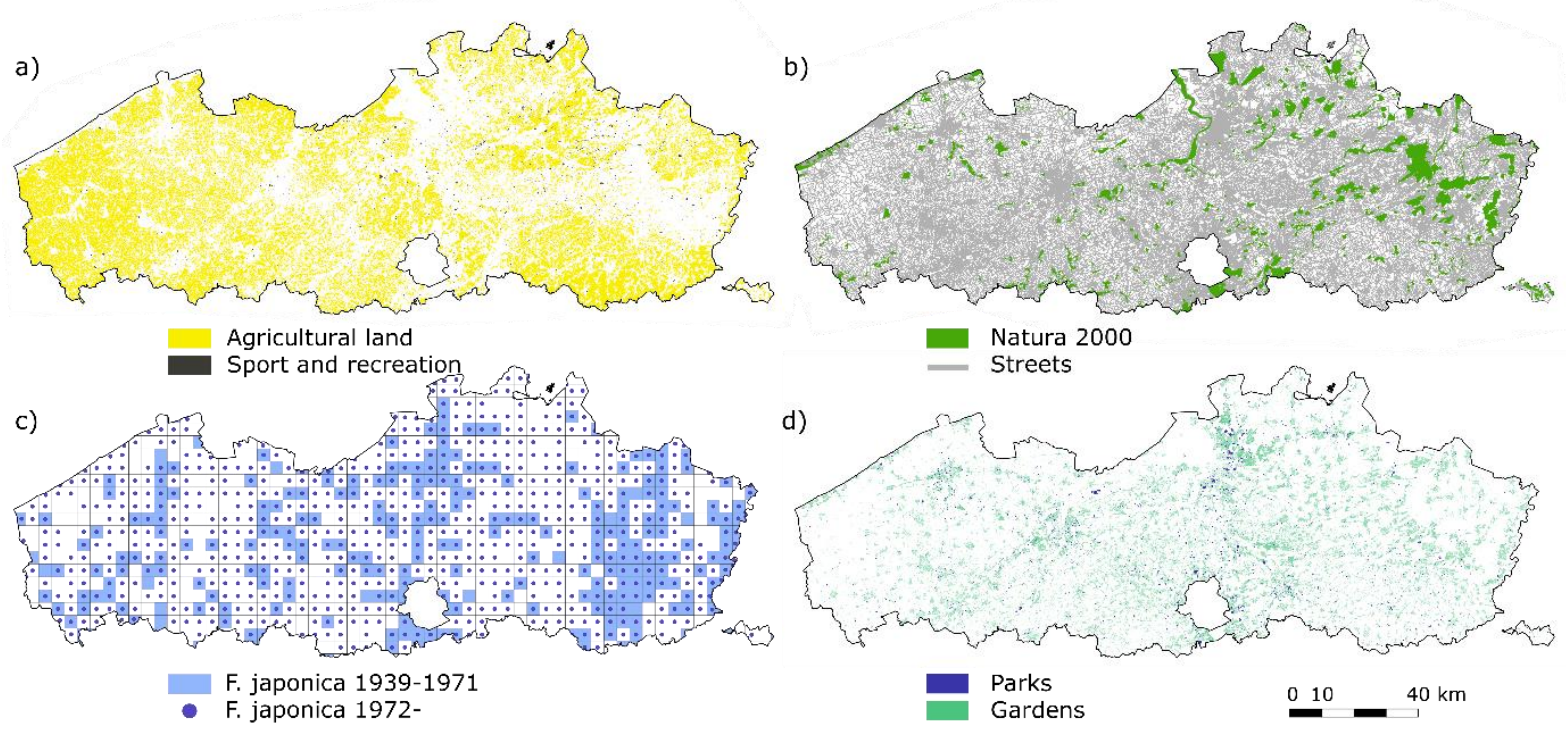

Fig. 4 Different land use categories in Flanders. a) HILD systems: Agricultural land and area for sport and recreation [116]. b) LIHD systems: Natura 2000 protected areas and road network [117, 118]. c) LILD systems: The spread of the invasive exotic plant Fallopia japonica in Flanders between 1939-1971 and 1972-now (4x4 km grid) [119]. d) HIHD systems: Gardens and parks [73, 116].

\subsection{High-Input Low-Diversity systems in Flanders}

HILD systems play a prominent role in Flanders. In 2015, 51\% (609,098 ha) of the total land area was cultivated for agriculture (Fig. 4a, [120]). Arable land takes the largest share of agricultural land (55\%), while pastures cover more than a third (36.5\%) and horticulture only $8.5 \%$. While most of the area is used for fodder production (pasture and maize), only a small percentage is used for the cultivation of bioenergy crops (Fig. 5). Estimates are between 2500 and 3500 hectares of silage maize for bioenergy production, 96 hectare of short rotation coppice and 33 hectares of Miscanthus for the period 2011-2012 [120, 121]. There are no data of other crops grown for energy purposes in Flanders. Total amount of bioenergy crop production is 49,060 Mg DM $\mathrm{yr}^{-1}$. Policies are lacking to stimulate this sector. The Flemish government stopped the financial support for bioenergy crop production in 2010 [115]. Sport fields and other recreation areas (Fig. 4a) also belong to the HILD category, but cover a much smaller area than agricultural land $(12,890 \mathrm{ha})$. However, the area that produces herbaceous biomass (5087 ha) is almost equal to that of bioenergy crops (Fig. 5, [122]). The total annual grass clippings production in sport fields and other recreation areas is estimated at $10,576-15,865 \mathrm{Mg}$ DM annually. 


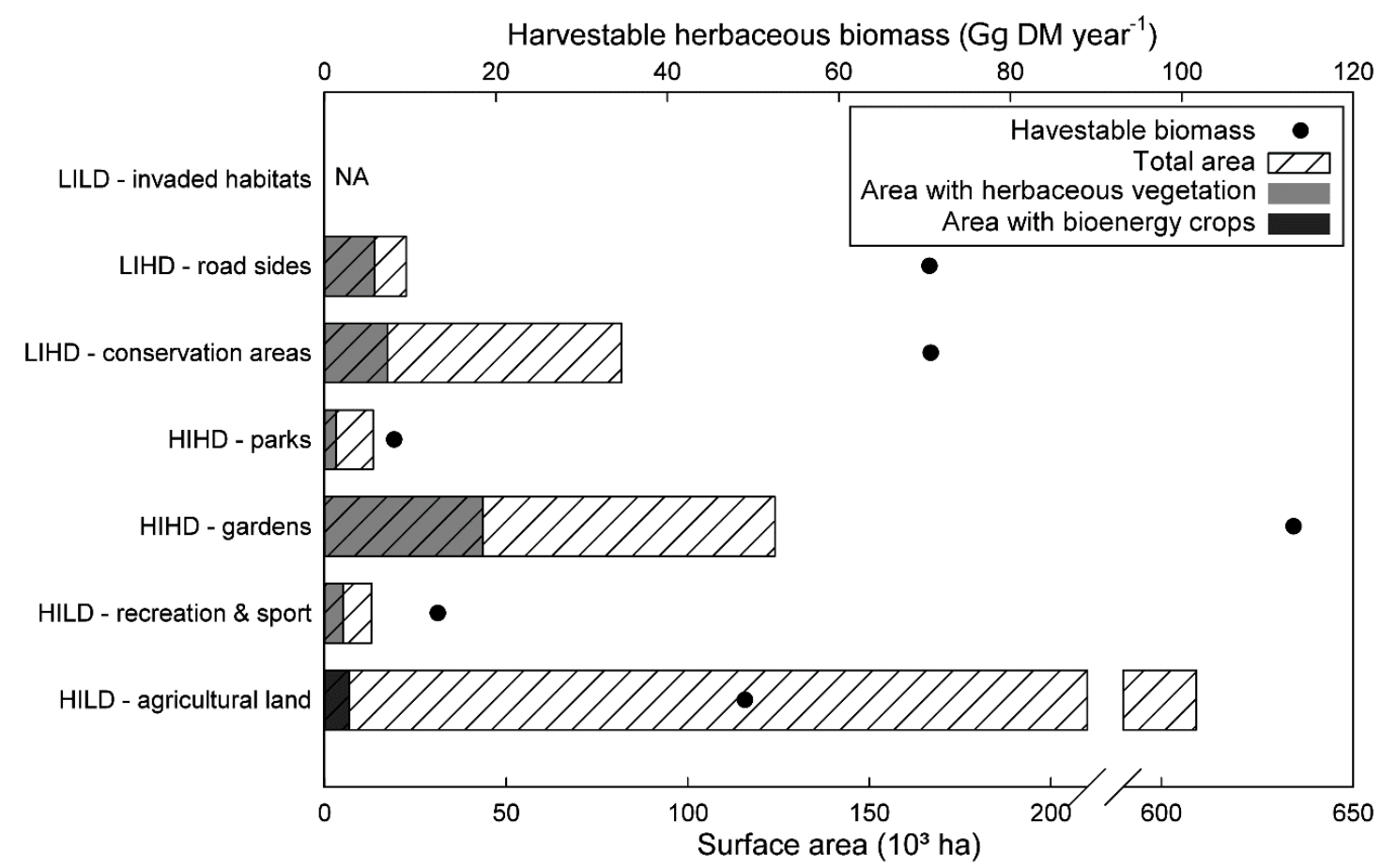

Fig. 5 Estimates of the current total area of landscape categories in Flanders and surface area of the part with herbaceous vegetation, suitable for bioenergy production (bars) and their annual harvestable, herbaceous biomass (circles). NA: not available. For data and references, see Appendix B

\subsection{Low-Input High-Diversity systems in Flanders}

The establishment of protected areas, like the Natura 2000 network is the cornerstone of biodiversity conservation in this highly urbanized region (Fig. 4b). Because of the high degree of urbanization, conservation areas are relatively small and heavily fragmented. In 2016, more than 81,500 ha of natural areas (including forests) was managed for biodiversity conservation [123], of which 17,250 ha are grasslands, marshes, fens, dunes and tall-herb vegetation with herbaceous vegetation. Each year, $70.74 \mathrm{Gg}$ DM of biomass could be harvested in conservation areas for bioenergy production, without degrading biodiversity values (Fig. 5 and [27]). Part of this area is grazed or mown for fodder today. However, when the forage quality is too low, the management clippings are left in the field on piles. The decomposition of the biomass leads to local nutrient enrichment with undesirable effects for biodiversity. With around $63,000 \mathrm{~km}$ roads, Flanders has a very high road network density $\left( \pm 4.65 \mathrm{~km} / \mathrm{km}^{2}\right.$, Fig. $\left.4 \mathrm{~b}\right)$. The total area of roadsides is estimated between 20,000 and 25,000 ha, although no accurate estimates exist [124]. Grassy roadsides cover almost two thirds (13,800 ha [27]). The remainder of the total area are paved surfaces or roadsides with woody vegetation. Every year, the management of roadsides produces $70.60 \mathrm{Gg}$ DM of grass clippings. Only a small part is composted, the rest is left in the field. The current total harvestable biomass in conservation areas and roadsides 
(141.33 Gg DM yr ${ }^{-1}$, Fig. 5) is higher than that of HIHD and HILD systems (Fig. 5). The total area of LIHD systems in Flanders is, however, more extensive than roadsides and conservation areas alone. The category also includes other land use classes like verges of waterways and railways. For these, only very rough estimates exist (Appendix B).

\subsection{Low-Input Low-Diversity systems in Flanders}

No spatially explicit information is available for LILD systems. Detailed spatial assessments are lacking because habitats invaded by alien species are often small and scattered. The Invasive Species Environmental Impact Assessment protocol categorizes invasive species in Belgium according to their impact and invasion stage [125]. Currently, ten vascular plant species are categorized as 'A3 black list species' (widespread species with a high impact). The herbaceous species in this category are all characterized by a high biomass production and have known a strong spread during the last decades (for an example see Fig. 4c). Van Meerbeek et al. [48] mapped the biomass yield of four herbaceous invasive plant species in this region (Fig. 2). Without appropriate measures, these species will spread even more and consequently, will have a high impact on the present biodiversity.

\subsection{High-Input High-Diversity systems in Flanders}

Gardens (usually HIHD systems) cover a substantial area in Flanders (ca. 9\% or 124,000 ha, Fig. 4d), with lawns as one of the major components $(43,500$ ha [71, 72]). With an average annual yield of 2.08-3.12 $\mathrm{Mg} \mathrm{DM} \mathrm{ha}^{-1}$, gardens produce between 90,450 and 135,675 Mg DM of grass clippings (Fig. 5). This biomass is partly composted at home or is processed together with kitchen waste by waste management companies. However, composting is not a financially attractive valorization method [126]. Parks also often harbor a lot of biodiversity and are managed intensively for esthetic reasons and recreational activities. The maintenance of park lawns (3,120 ha, Fig. 4d) provides annually between 6,490 and 9,740 Mg DM of grass clippings.

\subsection{Integrating biomass waste streams in Flanders}

In Flanders, the maintenance of almost 87,200 hectares (6.5\% of the total area of Flanders) conservation areas, verges, lawns of gardens, parks and other recreational areas produces every year almost $290 \mathrm{Gg}$ DM (or $1087 \mathrm{Gg}$ fresh) of herbaceous landscape biomass (Table 2 and appendix B). LILD systems are not included in these data, because of the lack of spatially 
explicit data. Although this is much more than bioenergy crop production in the same region (only $49 \mathrm{Gg}$ ), this biomass is not used as a bioenergy feedstock today. With 41 large-scale digesting facilities (power $>200 \mathrm{kWe}$ ) and 76 small-scale digesters, possibilities for biomass conversion through anaerobic digestion are widespread in Flanders [127]. This is an important requirement to keep transport costs within limits, and thus necessary for a profitable bioenergy system [27, 38]. Van Meerbeek et al. [27] mapped and optimized the biomass-for-bioenergy supply chain for biodegradable waste, pig slurry, silage maize and LIHD biomass for maximal net energy output. Modelling the full associated biomass-to-bioenergy supply chain (including harvest, pre-processing, transport and energy conversion) with the optimization model OPTIMASS [128], they found a NEB of $1.51 \mathrm{GJ} \mathrm{Mg}^{-1} \mathrm{DM}$ of conservation area or roadside biomass. In combination with the previous results, the bioenergy deployment of $290 \mathrm{Gg}$ DM landscape biomass through digestion would generate a net thermal and electrical energy output of $437.00 \mathrm{TJ}$ (or $121.38 \mathrm{GWh}$ ).

Landscape biomass can be combined with other waste sources in an integrated biomass-forbioenergy supply chain. Only fresh weight data for these waste streams are available in the literature and are reported here. Co-digestion of landscape biomass with manure provides the opportunity to process the manure surplus in Flanders. In 2016, 3.97 Tg of animal manure (fresh weight) was processed in Flanders (also including imported manure [129]). However, only 9.3\% was used for bioenergy production. Further, every inhabitant in Flanders produces on average $112.41 \mathrm{~kg}$ organic waste (kitchen and garden waste), summing up to a total of 724.39 Gg (fresh) in 2014 [130]. The food industry is a large producer of organic waste as well (2403.50 Gg fresh annually), of which $50 \%$ is processed as animal feed and almost $20 \%$ is already used in anaerobic digesters (in 2011 [131]). Other important sources of organic waste are the maintenance of green spaces, organic sludge (e.g. sewage sludge) and cooking oil from households and food industry (Table 2). Van Meerbeek et al. [27] report an average a gross energy production of $1.43 \mathrm{GJ} \mathrm{Mg}^{-1}$ fresh biomass for the digestion of mixed biomass feedstock (biodegradable waste, pig slurry, silage maize and LIHD biomass). Applying this figure, the bioenergy deployment of $8886.83 \mathrm{Gg}$ fresh waste biomass could generate 12.67 PJ (or 3518.67 $\mathrm{GWh}$ ) of renewable energy (thermal + electrical), which is $20 \%$ of the current renewable energy production $(17,905 \mathrm{GWh})$ or $1.3 \%$ of the total energy production in Flanders. Taking into account all energy inputs from harvest to energetic valorization, the total net energy output would be $6.46 \mathrm{PJ}$ or $1793,84 \mathrm{GWh}$. The energetic conversion of waste biomass can substantially contribute to achieving the renewable energy goals of Flanders. 
Table 2 Overview of the magnitude ( $\mathrm{Gg}$ fresh biomass $\mathrm{yr}^{-1}$ ) of different organic waste streams suitable for anaerobic digestion in Flanders (Belgium). Only fresh weight data are available for the different biomass waste streams (except landscape biomass)

\begin{tabular}{|c|c|c|}
\hline Waste biomass & Gg biomass (fresh) & Ref \\
\hline Landscape biomass* $^{*}$ & 1087.00 & \\
\hline Animal manure $\ddagger$ & 3972.44 & [129] \\
\hline Organic waste - households (kitchen and garden waste) ${ }^{\star \star}$ & 724.39 & [130] \\
\hline $\begin{array}{l}\text { Organic waste - maintenance of green spaces by governments and } \\
\text { municipalities }{ }^{\dagger}\end{array}$ & 88.24 & [131] \\
\hline Organic waste - maintenance of green spaces by companies & 247.74 & [131] \\
\hline Industrial organic waste - food industry & 2403.50 & [131] \\
\hline Organic sludge & 685.42 & [131] \\
\hline Cooking oil from households and industry & 19.88 & [131] \\
\hline
\end{tabular}

${ }^{*}$ Biomass from roadsides, protected areas, gardens, parks and sport fields. Assumption: $60-80 \%$ moisture content ¥ Processed manure. No data available for manure production

** This category also includes the lawn clippings that are collected by waste management companies. To avoid double counting (lawn clippings are also included in landscape biomass), the amount of garden waste was subtracted, as determined in [130], from the total. This is an approximation, because data are lacking of the amount of lawn clippings in this category

${ }^{\dagger}$ excluding the land uses included in the category landscape biomass

\section{Discussion}

\subsection{Landscape management as a biomass source}

The landscape beyond agricultural land and forests provides a large biomass-for-bioenergy potential that is only marginally valorized today. First generation biofuels are often net carbon sources when taking emissions from indirect land-use change into account [10, 47], and compete with food production for land and biomass [132]. Bioenergy from landscape biomass avoids this competition and could offset indirect land-use change [35]. Here, an overview was given of the biomass and bioenergy potential of three landscape categories in the anthropogenic input-biodiversity continuum: Low-Input High-Diversity (LIHD), Low-Input Low-Diversity (LILD) and High-Input High-Diversity (HIHD). The annual biomass production varies considerably between the different categories but is consistently lower than in High-Input LowDiversity (HILD) systems, which represent most of the current agricultural land. The production function of the latter category is optimized through the use of fertilizers, irrigation and pesticides.

The considered landscape categories are not managed for biomass production, but their maintenance delivers other important benefits to society. The biodiversity in conservation areas 
contributes to human well-being by providing benefits to society like carbon sequestration, air filtering, water purification, and pollination [133]. The global monetary value of these so-called ecosystem services amounts to $\$ 125$ trillion per year (in 2011 [134]). Eradication of invasive species aims at the restoration of native biodiversity and its ecosystem services. In the long term, this biomass feedstock will not be renewable at a local scale. However, at a larger scale, the area invaded with exotic species is likely to increase in the future due to increased globalization and climate change $[135,136]$. Verges of roads and railways are managed to maintain visibility and to prevent encroachment, while verges of small waterways are often mown to maintain the water-draining function and dike stability. Gardens and urban green are intensively managed for esthetic and recreational purposes and have clear benefits for human health by promoting physical activity, reducing stress levels, ameliorating air pollution, and reducing the urban heat island effect [137]. Conversion of this biomass to energy will provide a financial incentive for proper management, which in turn optimizes the delivery of ecosystem services to society [38]. Instead of treating the harvested biomass as waste, one could consider it as co-benefit and use it as a resource. Maximizing the biomass production would, however, result in the degradation of the other ecosystem services [138].

The bioenergy deployment of landscape biomass could be promising in urban areas where the management and the collection of the biomass is well organized. The case study clearly showed this urban potential by quantifying the biomass potential in the region of Flanders (Belgium), which serves as a model for urbanized regions in a temperate climate. Every year, the management of 87,200 hectares of roadsides, lawns, sport fields and conservation areas $(6.5 \%$ of the total area of Flanders) could generate almost $290 \mathrm{Gg}$ dry matter (or $1087 \mathrm{Gg}$ fresh) of herbaceous biomass. This is even without the biomass originating from the restoration of areas invaded by invasive alien species. No spatial data are available for these LILD-system, but the problem of invasive species is certain to grow in the future [136]. The case study further shows that synergies could arise from the joint collection, preprocessing and conversion with other organic waste streams (e.g. industrial organic waste, cooking oil, organic sludge) that are abundantly available in urban regions. Combined together, the available waste biomass in Flanders amounts to $8,886 \mathrm{Gg}$ of fresh biomass per year. Integrating this surplus biomass in the existing anaerobic digestion chain could produce $12.67 \mathrm{PJ}$ or $20 \%$ of the current renewable energy production of Flanders. 


\subsection{Challenges and recommendations for landscape bioenergy}

The spatially scattered occurrence and seasonal variation in biomass availability of landscape biomass pose a great challenge for transport and handling and leads to potentially expensive and unstable supplies. Solutions to overcome these barriers are necessary to put bioenergy deployment of landscape biomass into practice. [e.g. 27]. Decentralized biomass utilization or preprocessing (e.g. IFBB, torrefaction) to densify the voluminous biomass could reduce logistical problems and transporation costs [139]. Long-term storage of biomass as silage or as stable intermediates after preprocessing could stabilize temporal irregular supply patterns [37]. In addittion, supply chain management and network optimization can stimulate the integration of landscape biomass with other waste streams into efficient regional bioenergy networks [140]. Tuning the different supply chains will result in a more stable supply of feedstock and reduces the costs by combing transport and by gaining economies of scale. The use of time- and spaceexplicit strategic optimization models like OPTIMASS [128] might be a big step forward to put supply chain management and optimization into practice. Detailed spatial data are however necessary [27], which is a limitation on the current applicability of these models. Spatial assessments of biomass availability, as performed in the case study, can fill current knowledge gaps. The low conversion efficiency of anaerobic digestion of lignocellulosic landscape biomass (10-30\% [89]) is another bottleneck towards landscape bioenergy. Technologies to increase the efficiency are existing (e.g. IFBB [141]), but are not commercially available yet. More research will be needed to move currently available bioenergy techniques beyond the development phase and design cost-competitive, small-scale biomass conversion pathways. Finally, the development of new valorization chains or the integration of landscape biomass in existing chains will largely depend on the economic viability. Although landscape biomass is a cheap biomass feedstock (or could even be free), due to current low conversion efficiency and high transport and handling costs, HILD biomass or fossil fuels are still financially more attractive [27]. The incorporation of the monetary value of the ecosystem services provided by landscape management and the disservices of HILD systems would most likely tip the balance. Nevertheless, besides technological advances, governmental incentives, like renewable energy certificates or high carbon pricing [142, 143], will be necessary to stimulate landscape biomass deployment. If society wants to move forward on a more sustainable track [144], it should opt for more sustainable renewable energy sources, without negative effects on food security or the environment. Financial support or other stimuli for more sustainable, but less financially attractive bioenergy systems are then a logical choice. The focus of this review was mainly on 
bioenergy production, but other valorization pathways, like biorefinery are at hand [139, 145, 146].

\section{Conclusions}

Bioenergy is assigned an important role in the roadmap towards a decarbonized society [4]. We urgently need to look for other more sustainable sources of bioenergy without adverse effects on food security and the environment. This study explored the biomass-for-bioenergy potential in the landscape beyond agricultural land and forests: gardens, roadsides, conservation areas, sport fields etc. The large amount of surplus biomass that is created by their regular management should not be regarded as waste but as a sustainable bioenergy resource. The annual biomass productivity in these systems is lower than that of crops grown on intensive agricultural land (2.0-9.2 Mg vs 12.0-20.4 Mg dry matter per year). Further optimizing the biomass production is, however, not an option, as there is a trade-off between this function and the other ecosystem services the landscape offers. Taking into account the energy expenditure related to the whole valorization process, landscape bioenergy does have the potential of creating a higher net energy balance (NEB) than that of some of the current bioenergy systems. In urban areas, biomass from landscape management is abundantly available and could be valorized together with other organic waste streams. In the urbanized region of Flanders (Western Europe), anaerobic digestion of the total amount of annually available organic waste could generate $20 \%$ of the current renewable energy production in the study region. Although bioenergy from landscape biomass does not generate profit margins as high as HILD systems $[27,36]$, it could contribute to renewable energy goals, if supported by policy instruments such as carbon pricing or renewable energy subsidies [143]. Policy makers should further stimulate the development of networks of local decentralized production facilities and research on bioenergy conversion technologies. In addition, spatial assessments of biomass availability are necessary to develop efficient, regional biomass supply chains.

\section{Acknowledgements}

We would like to thank Jeroen Degerickx for his help with ArcGIS and the three anonymous reviewers for their comments and suggestions. The research on which this article is based was funded by a postdoc grant of KU Leuven (PDM 3E150537). 


\section{References}

[1] Schleussner C-F, Lissner TK, Fischer EM, Wohland J, Perrette M, Golly A, et al. Differential climate impacts for policy-relevant limits to global warming: the case of $1.5 \mathrm{C}$ and $2 \mathrm{C}$. Earth system dynamics. 2016;7:327-51.

[2] IPCC. Climate Change 2014: Synthesis Report. Contribution of Working Groups I, II and III to the Fifth Assessment Report of the Intergovernmental Panel on Climate Change. In: Pachauri RK, Meyer LA, editors. Geneva, Switzerland: Cambridge University Press; 2014. p. 151.

[3] IPCC. Global warming of $1.5^{\circ} \mathrm{C}$ - Summary for Policymakers. IPCC; 2018. p. 33.

[4] Rockström J, Gaffney O, Rogelj J, Meinshausen M, Nakicenovic N, Schellnhuber HJ. A roadmap for rapid decarbonization. Science. 2017;355:1269-71.

[5] IEA. Key World Energy Statistics. Paris: International Energy Agency; 2017. p. 95.

[6] Canadell JG, Schulze ED. Global potential of biospheric carbon management for climate mitigation. Nat Commun. 2014;5.

[7] Rogelj J, Luderer G, Pietzcker RC, Kriegler E, Schaeffer M, Krey V, et al. Energy system transformations for limiting end-of-century warming to below 1.5 C. Nat Clim Change. 2015;5:519.

[8] Slade R, Bauen A, Gross R. Global bioenergy resources. Nature Clim Change. 2014;4:99-105.

[9] Hertel TW. The Global Supply and Demand for Agricultural Land in 2050: A Perfect Storm in the Making?1. Am J Agr Econ. 2011;93:259-75.

[10] Searchinger T, Heimlich R, Houghton RA, Dong F, Elobeid A, Fabiosa J, et al. Use of U.S. croplands for biofuels increases greenhouse gases through emissions from land-use change. Science. 2008;319:1238-40.

[11] Lorenz K, Rattan L. Biomass and Bioenergy. In: Lorenz K, Rattan L, editors. Carbon Sequestration in Agricultural Ecosystems: Springer; 2018. p. 261-99.

[12] Creutzig F, Ravindranath NH, Berndes G, Bolwig S, Bright R, Cherubini F, et al. Bioenergy and climate change mitigation: an assessment. GCB Bioenergy. 2015;7:916-44.

[13] Hudiburg TW, Law BE, Wirth C, Luyssaert S. Regional carbon dioxide implications of forest bioenergy production. Nat Clim Change. 2011;1:419-23.

[14] Schulze ED, Korner CI, Law BE, Haberl H, Luyssaert S. Large-scale bioenergy from additional harvest of forest biomass is neither sustainable nor greenhouse gas neutral. Global Change Biology Bioenergy. 2012;4:611-6.

[15] Zanchi G, Pena N, Bird N. Is woody bioenergy carbon neutral? A comparative assessment of emissions from consumption of woody bioenergy and fossil fuel. Global Change Biology Bioenergy. 2012;4:761-72.

[16] Tilman D, Hill J, Lehman C. Carbon-negative biofuels from low-input high-diversity grassland biomass. Science. 2006;314:1598-600.

[17] Ericsson K, Nilsson LJ. Assessment of the potential biomass supply in Europe using a resource-focused approach. Biomass and Bioenergy. 2006;30:1-15.

[18] Bentsen NS, Felby C. Biomass for energy in the European Union - a review of bioenergy resource assessments. Biotechnology for Biofuels. 2012;5.

[19] Smeets E, Faaij A, Lewandowski I, Turkenburg W. A bottom-up assessment and review of global bio-energy potentials to 2050. Progress in Energy and Combustion Science. 2007;33:56-106. [20] Verkerk PJ, Anttila P, Eggers J, Lindner M, Asikainen A. The realisable potential supply of woody biomass from forests in the European Union. Forest Ecol Manag. 2011;261:2007-15.

[21] Corton J, Bühle L, Wachendorf M, Donnison IS, Fraser MD. Bioenergy as a biodiversity management tool and the potential of a mixed species feedstock for bioenergy production in Wales. Bioresour Technol. 2013;129:142-9.

[22] Britton AJ, Marrs RH, Carey PD, Pakeman RJ. Comparison of techniques to increase Calluna vulgaris cover on heathland invaded by grasses in Breckland, south east England. Biological Conservation. 2000;95:227-32.

[23] Niemeyer M, Niemeyer T, Fottner S, Hardtle W, Mohamed A. Impact of sod-cutting and choppering on nutrient budgets of dry heathlands. Biological Conservation. 2007;134:344-53. 
[24] Saha M, Eckelman MJ. Geospatial assessment of potential bioenergy crop production on urban marginal land. Applied Energy. 2015;159:540-7.

[25] Milbrandt AR, Heimiller DM, Perry AD, Field CB. Renewable energy potential on marginal lands in the United States. Renewable and Sustainable Energy Reviews. 2014;29:473-81.

[26] Gelfand I, Sahajpal R, Zhang XS, Izaurralde RC, Gross KL, Robertson GP. Sustainable bioenergy production from marginal lands in the US Midwest. Nature. 2013;493:514-7.

[27] Van Meerbeek K, Ottoy S, De Meyer A, Van Schaeybroeck T, Van Orshoven J, Muys B, et al. The bioenergy potential of conservation areas and roadsides for biogas in an urbanized region. Applied Energy. 2015;154:742-51.

[28] Ostermann OP. The need for management of nature conservation sites designated under Natura 2000. Journal of Applied Ecology. 1998;35:968-73.

[29] Plieninger T, Hochtl F, Spek T. Traditional land-use and nature conservation in European rural landscapes. Environ Sci Policy. 2006;9:317-21.

[30] Cop J, Vidrih M, Hacin J. Influence of cutting regime and fertilizer application on the botanical composition, yield and nutritive value of herbage of wet grasslands in Central Europe. Grass and Forage Science. 2009;64:454-65.

[31] Bovolenta S, Spanghero M, Dovier S, Orlandi D, Clementel F. Chemical composition and net energy content of alpine pasture species during the grazing season. Anim Feed Sci Tech. 2008;140:164-77.

[32] Fiems LO, De Boever JL, De Vliegher A, Vanacker JM, De Brabander DL, Carlier L. Agrienvironmental grass hay: Nutritive value and intake in comparison with hay from intensively managed grassland. Arch Anim Nutr. 2004;58:233-44.

[33] Tikka P, Högmander H, Koski P. Road and railway verges serve as dispersal corridors for grassland plants. Landscape Ecology. 2001;16:659-66.

[34] Kahmen S, Poschlod P, Schreiber KF. Conservation management of calcareous grasslands. Changes in plant species composition and response of functional traits during 25 years. Biological Conservation. 2002;104:319-28.

[35] Van Meerbeek K, Ottoy S, Garcia MD, Muys B, Hermy M. The bioenergy potential of Natura 2000-a synergy between climate change mitigation and biodiversity protection. Front Ecol Environ. 2016;14:473-8.

[36] Meyer AKP, Ehimen EA, Holm-Nielsen JB. Bioenergy production from roadside grass: A case study of the feasibility of using roadside grass for biogas production in Denmark. Resources, Conservation and Recycling. 2014;93:124-33.

[37] Piepenschneider M, Buhle L, Hensgen F, Wachendorf M. Energy recovery from grass of urban roadside verges by anaerobic digestion and combustion after pre-processing. Biomass Bioenerg. 2016;85:278-87.

[38] Pedroli B, Elbersen B, Frederiksen P, Grandin U, Heikkilä R, Krogh PH, et al. Is energy cropping in Europe compatible with biodiversity? - Opportunities and threats to biodiversity from land-based production of biomass for bioenergy purposes. Biomass and Bioenergy. 2013;55:73-86. [39] Allen B, Kretschmer B, Baldock D, Menadue H, Nanni S, Tucker G. Space for energy crops - assessing the potential contribution to Europe's energy future. London: IEEP; 2014. p. 63.

[40] ETC/SIA. Review of the EU bioenergy potential from a resource efficiency perspective. Wageningen: Alterra; 2013. p. 305.

[41] de Wit M, Faaij A. European biomass resource potential and costs. Biomass Bioenerg. 2010;34:188-202.

[42] EC. The EU's protected areas - Natura 2000. 2014.

[43] ERF. Road statistics - Yearbook 2016. Brussels: European Union Road Federation; 2016. p. 90.

[44] Valentine J, Clifton-Brown J, Hastings A, Robson P, Allison G, Smith P. Food vs. fuel: the use of land for lignocellulosic 'next generation' energy crops that minimize competition with primary food production. GCB Bioenergy. 2012;4:1-19. 
[45] Hill J, Nelson E, Tilman D, Polasky S, Tiffany D. Environmental, economic, and energetic costs and benefits of biodiesel and ethanol biofuels. Proc Natl Acad Sci U S A. 2006;103:1120610.

[46] Don A, Osborne B, Hastings A, Skiba U, Carter MS, Drewer J, et al. Land-use change to bioenergy production in Europe: implications for the greenhouse gas balance and soil carbon. Global Change Biology Bioenergy. 2012;4:372-91.

[47] Fargione J, Hill J, Tilman D, Polasky S, Hawthorne P. Land clearing and the biofuel carbon debt. Science. 2008;319:1235-8.

[48] Van Meerbeek K, Appels L, Dewil R, Calmeyn A, Lemmens P, Muys B, et al. Biomass of invasive plant species as a potential feedstock for bioenergy production. Biofuels, Bioproducts and Biorefining. 2015;9:273-82.

[49] Colautti RI, Ricciardi A, Grigorovich IA, MacIsaac HJ. Is invasion success explained by the enemy release hypothesis? Ecology Letters. 2004;7:721-33.

[50] Blossey B, Notzold R. Evolution of Increased Competitive Ability in Invasive Nonindigenous Plants - a Hypothesis. Journal of Ecology. 1995;83:887-9.

[51] Strašil Z, Kára J. Study of knotweed (Reynoutria) as possible phytomass resource for energy and industrial utilization. Research of Agricultural Engineering. 2010:85-91.

[52] Sage RF, Coiner HA, Way DA, Brett Runion G, Prior SA, Allen Torbert H, et al. Kudzu [Pueraria montana (Lour.) Merr. Variety lobata]: A new source of carbohydrate for bioethanol production. Biomass and Bioenergy. 2009;33:57-61.

[53] Vilà M, Espinar JL, Hejda M, Hulme PE, Jarosik V, Maron JL, et al. Ecological impacts of invasive alien plants: a meta-analysis of their effects on species, communities and ecosystems. Ecology Letters. 2011;14:702-8.

[54] Pejchar L, Mooney HA. Invasive species, ecosystem services and human well-being. Trends Ecol Evol. 2009;24:497-504.

[55] Mack RN, Lonsdale WM. Eradicating invasive plants: hard-won lessons for islands. In: Veitch D, Clout M, editors. Turning the Tide: the Eradication of Invasive Species. Auckland, New Zealand: IUCN; 2002. p. 164-72.

[56] Davis AS, Cousens RD, Hill J, Mack RN, Simberloff D, Raghu S. Screening bioenergy feedstock crops to mitigate invasion risk. Front Ecol Environ. 2010;8:533-9.

[57] Barney JN, Ditomaso JM. Nonnative species and bioenergy: Are we cultivating the next invader? BioScience. 2008;58:64-70.

[58] Young SL, Gopalakrishnan G, Keshwani DR. Invasive plant species as potential bioenergy producers and carbon contributors. J Soil Water Conserv. 2011;66:45a-50a.

[59] Jakubowski AR, Casler MD, Jackson RD. The Benefits of Harvesting Wetland Invaders for Cellulosic Biofuel: An Ecosystem Services Perspective. Restor Ecol. 2010;18:789-95.

[60] Nackley LL, Lieu VH, Garcia BB, Richardson JJ, Isaac E, Spies K, et al. Bioenergy that supports ecological restoration. Front Ecol Environ. 2013;11:535-40.

[61] Patova OA, Golovchenko VV, Vityazev FV, Burkov AA, Belyi VA, Kuznetsov SN, et al. Physicochemical and rheological properties of gelling pectin from Sosnowskyi's hogweed (Heracleum sosnowskyi) obtained using different pretreatment conditions. Food Hydrocolloids. 2017;65:77-86.

[62] Glaser A, Glick P. Growing Risk: Addressing the invasive potential of bioenergy feedstocks. Washington, DC: National Wildlife Federation; 2012.

[63] Quinn LD, Barney JN, McCubbins JSN, Endres AB. Navigating the "Noxious" and "Invasive" Regulatory Landscape: Suggestions for Improved Regulation. BioScience. 2013;63:124-31.

[64] Loram A, Thompson K, Warren PH, Gaston KJ. Urban domestic gardens (XII): The richness and composition of the flora in five UK cities. J Veg Sci. 2008;19:321-30.

[65] Smith RM, Thompson K, Hodgson JG, Warren PH, Gaston KJ. Urban domestic gardens (IX): composition and richness of the vascular plant flora, and implications for native biodiversity. Biological Conservation. 2006;129:312-22. 
[66] Chamberlain DE, Cannon AR, Toms MP, Leech DI, Hatchwell BJ, Gaston KJ. Avian productivity in urban landscapes: a review and meta-analysis. Ibis. 2009;151:1-18.

[67] Matteson KC, Langellotto GA. Determinates of inner city butterfly and bee species richness. Urban Ecosystems. 2010;13:333-47.

[68] Bergerot B, Fontaine B, Renard M, Cadi A, Julliard R. Preferences for exotic flowers do not promote urban life in butterflies. Landscape and Urban Planning. 2010;96:98-107.

[69] Robbins P, Birkenholtz T. Turfgrass revolution: measuring the expansion of the American lawn. Land Use Policy. 2003;20:181-94.

[70] Law N, Band L, Grove M. Nitrogen input from residential lawn care practices in suburban watersheds in Baltimore County, MD. Journal of Environmental Planning and Management. 2004; 47:737-55.

[71] Dewaelheyns V, Elsen A, Vandendriessche H, Gulinck H. Garden management and soil fertility in Flemish domestic gardens. Landscape and Urban Planning. 2013;116:25-35.

[72] Dewaelheyns V, Rogge E, Gulinck H. Putting domestic gardens on the agenda using empirical spatial data: The case of Flanders. Applied Geography. 2014;50:132-43.

[73] Michels H, Stevens M. Het ecosysteemdienstenconcept als ondersteuning van bovenlokale visievorming - Natuurrapport, Aan de slag met ecosysteemdiensten. Brussels: Instituut voor Natuur- en Bosonderzoek; 2016. p. 100.

[74] Davies ZG, Fuller RA, Loram A, Irvine KN, Sims V, Gaston KJ. A national scale inventory of resource provision for biodiversity within domestic gardens. Biological Conservation. 2009;142:761-71.

[75] Colding J, Lundberg J, Folke C. Incorporating green-area user groups in urban ecosystem management. AMBIO: A Journal of the Human Environment. 2006;35:237-44.

[76] Loram A, Tratalos J, Warren PH, Gaston KJ. Urban domestic gardens (X): the extent \& structure of the resource in five major cities. Landscape Ecology. 2007;22:601-15.

[77] Mathieu R, Freeman C, Aryal J. Mapping private gardens in urban areas using object-oriented techniques and very high-resolution satellite imagery. Landscape and Urban Planning. 2007;81:17992.

[78] Blanco-Montero CA, Bennett TB, Neville P, Crawford CS, Milne BT, Ward CR. Potential environmental and economic impacts of turfgrass in Albuquerque, New Mexico (USA). Landscape Ecology. 1995;10:121-8.

[79] Springer TL. Biomass yield from an urban landscape. Biomass Bioenerg. 2012;37:82-7.

[80] Milesi C, Running SW, Elvidge CD, Dietz JB, Tuttle BT, Nemani RR. Mapping and modeling the biogeochemical cycling of turf grasses in the United States. Environ Manage. 2005;36:426-38.

[81] Walker KS, Bigelow CA, Smith DR, Van Scoyoc GE, Reicher ZJ. Aboveground responses of cool-season lawn species to nitrogen rates and application timings. Crop Science. 2007;47:1225-36.

[82] Qian Y, Bandaranayake W, Parton W, Mecham B, Harivandi M, Mosier A. Long-term effects of clipping and nitrogen management in turfgrass on soil organic carbon and nitrogen dynamics. Journal of Environmental Quality. 2003;32:1694-700.

[83] Tonn B, Thumm U, Claupein W. Semi-natural grassland biomass for combustion: influence of botanical composition, harvest date and site conditions on fuel composition. Grass and Forage Science. 2010;65:383-97.

[84] Rosburg A, Miranowski J, Jacobs K. Modeling biomass procurement tradeoffs within a cellulosic biofuel cost model. Energy Economics. 2016;58:77-83.

[85] Obernberger I. Decentralized biomass combustion: state of the art and future development. Biomass and Bioenergy. 1998;14:33-56.

[86] Appels L, Lauwers J, Degrève J, Helsen L, Lievens B, Willems K, et al. Anaerobic digestion in global bio-energy production: Potential and research challenges. Renewable and Sustainable Energy Reviews. 2011;15:4295-301.

[87] Prochnow A, Heiermann M, Plöchl M, Linke B, Idler C, Amon T, et al. Bioenergy from permanent grassland - A review: 1. Biogas. Bioresour Technol. 2009;100:4931-44. 
[88] Prochnow A, Heiermann M, Plöchl M, Amon T, Hobbs PJ. Bioenergy from permanent grassland - A review: 2. Combustion. Bioresour Technol. 2009;100:4945-54.

[89] Van Meerbeek K, Appels L, Dewil R, Van Beek J, Bellings L, Liebert K, et al. Energy potential for combustion and anaerobic digestion of biomass from Low-Input High-Diversity systems in conservation areas. GCB Bioenergy. 2015;7:888.

[90] Tonn B, Thumm U, Lewandowski I, Claupein W. Leaching of biomass from semi-natural grasslands - Effects on chemical composition and ash high-temperature behaviour. Biomass Bioenerg. 2012;36:390-403.

[91] Caputo AC, Palumbo M, Pelagagge PM, Scacchia F. Economics of biomass energy utilization in combustion and gasification plants: effects of logistic variables. Biomass Bioenerg. 2005;28:3551.

[92] Hensgen F, Bühle L, Donnison I, Frasier M, Vale J, Corton J, et al. Mineral concentrations in solid fuels from European semi-natural grasslands after hydrothermal conditioning and subsequent mechanical dehydration. Bioresour Technol. 2012;118:332-42.

[93] Ward AJ, Hobbs PJ, Holliman PJ, Jones DL. Optimisation of the anaerobic digestion of agricultural resources. Bioresour Technol. 2008;99:7928-40.

[94] Tadesse H, Luque R. Advances on biomass pretreatment using ionic liquids: An overview. Energy \& Environmental Science. 2011;4:3913-29.

[95] Kataeva I, Foston MB, Yang S-J, Pattathil S, Biswal AK, Poole Ii FL, et al. Carbohydrate and lignin are simultaneously solubilized from unpretreated switchgrass by microbial action at high temperature. Energy \& Environmental Science. 2013;6:2186-95.

[96] Six W, Debaere L. Dry anaerobic conversion of municipal solid-waste by means of the DRANCO process. Water Sci Technol. 1992;25:295-300.

[97] Wachendorf M, Richter F, Fricke T, Graß R, Neff R. Utilization of semi-natural grassland through integrated generation of solid fuel and biogas from biomass. I. Effects of hydrothermal conditioning and mechanical dehydration on mass flows of organic and mineral plant compounds, and nutrient balances. Grass and Forage Science. 2009;64:132-43.

[98] Piepenschneider M, Bühle L, Hensgen F, Wachendorf M. Energy recovery from grass of urban roadside verges by anaerobic digestion and combustion after pre-processing. Biomass and Bioenergy. 2016;85:278-87.

[99] Hensgen F, Richter F, Wachendorf M. Integrated generation of solid fuel and biogas from green cut material from landscape conservation and private households. Bioresour Technol. 2011;102:10441-50.

[100] Nitsche M, Hensgen F, Wachendorf M. Using Grass Cuttings from Sports Fields for Anaerobic Digestion and Combustion. Energies. 2017;10:388.

[101] Bühle L, Reulein J, Stülpnagel R, Zerr W, Wachendorf M. Methane Yields and Digestion Dynamics of Press Fluids from Mechanically Dehydrated Maize Silages Using Different Types of Digesters. BioEnergy Research. 2012;5:294-305.

[102] Hensgen F, Wachendorf M. The Effect of the Invasive Plant Species Lupinus polyphyllus Lindl. on Energy Recovery Parameters of Semi-Natural Grassland Biomass. Sustainability. 2016;8:998.

[103] Van Poucke R, Nachenius RW, Agbo KE, Hensgen F, Bühle L, Wachendorf M, et al. Mild hydrothermal conditioning prior to torrefaction and slow pyrolysis of low-value biomass. Bioresour Technol. 2016;217:104-12.

[104] Chen W-H, Peng J, Bi XT. A state-of-the-art review of biomass torrefaction, densification and applications. Renewable and Sustainable Energy Reviews. 2015;44:847-66.

[105] Chew JJ, Doshi V. Recent advances in biomass pretreatment - Torrefaction fundamentals and technology. Renewable and Sustainable Energy Reviews. 2011;15:4212-22.

[106] Nachenius RW, Ronsse F, Venderbosch RH, Prins W. Chapter Two - Biomass Pyrolysis. In: Murzin DY, editor. Advances in Chemical Engineering: Academic Press; 2013. p. 75-139. 
[107] Xu F, Linnebur K, Wang D. Torrefaction of Conservation Reserve Program biomass: A techno-economic evaluation. Industrial Crops and Products. 2014;61:382-7.

[108] Corton J, Donnison IS, Patel M, Bühle L, Hodgson E, Wachendorf M, et al. Expanding the biomass resource: sustainable oil production via fast pyrolysis of low input high diversity biomass and the potential integration of thermochemical and biological conversion routes. Applied Energy. 2016;177:852-62.

[109] Eurostat. Population statistics. European Commission; 2017.

[110] UN. World Urbanization Prospects: The 2014 Revision. United Nations, Department of Economic and Social Affairs, Population Division; 2015.

[111] Seto KC, Fragkias M, Guneralp B, Reilly MK. A Meta-Analysis of Global Urban Land Expansion. PLoS One. 2011;6.

[112] Jespers K, Aernouts K, Wetzels W. Inventaris hernieuwbare energiebronnen Vlaanderen 2005-2015. Mol: VITO; 2016.

[113] VITO. Inventaris hernieuwbare energie in Vlaanderen 2016. Mol: VITO; 2017. p. 10.

[114] EC. Directive 2009/28/EC of the European Parliament and of the Council of 23 April 2009 on the promotion of the use of energy from renewable sources and amending and subsequently repealing Directives 2001/77/EC and 2003/30/EC. 2009.

[115] emis.vito.be. Subdoelstellingen hernieuwbare energie: minder biomassa. emis.vito.be; 2017.

[116] De Saeger S, Ameeuw G, Berten B, Bosch H, Brichau I, De Knijf G, et al. Biologische Waarderingskaart, versie 2.2. Rapporten van het Instituut voor Natuur- en Bosonderzoek 2010 (36). Brussel: Instituut voor Natuur- en Bosonderzoek; 2010.

[117] DG ENV. Natura 2000 data - the European network of protected sites. Directorate General for Environment of the European Commission; 2013.

[118] Informatie Vlaanderen. Grootschalig referentiebestand. 2017.

[119] Van Landuyt W, Vanhecke L, Brosens D. Florabank1: a grid-based database on vascular plant distribution in the northern part of Belgium (Flanders and the Brussels Capital region). PhytoKeys. 2012:59.

[120] Platteau J, Van Gijseghem D, Van Bogaert T, Vuylsteke A. Landbouw- en visserijrapport 2016. Brussel: Departement Landbouw en Visserij; 2016.

[121] Van Kerckvoorde A, Van Reeth W. Hoofdstuk 14 - Ecosysteemdienst productie van energiegewassen. In: Stevens Mea, editor. Natuurrapport - Toestand en trend van ecosystemen en ecosysteemdiensten in Vlaanderen Technisch rapport Mededelingen van het Instituut voor Natuuren Bosonderzoek. Brussels2014.

[122] Poelmans L, Van Daele T. Landgebruikskaart NARA-T 2014. Mol: VITO; 2014. p. 45.

[123] INBO. Oppervlakte 'met effectief natuurbeheer' - Natuurindicatoren 2017: toestand van de natuur in Vlaanderen cijfers voor het beleid. Mededelingen van het Instituut voor Natuur- en Bosonderzoek. Brussel: Instituut voor Natuur- en Bosonderzoek; 2017.

[124] Informatie Vlaanderen. Beheer van de wegbermen in Vlaanderen. Brussels2017.

[125] Branquart E. Guidelines for environmental impact assessment and list classification of nonnative organisms in Belgium. 2007.

[126] Faaij A, Van Ree R, Waldheim L, Olsson E, Oudhuis A, Van Wijk A, et al. Gasification of biomass wastes and residues for electricity production. Biomass and Bioenergy. 1997;12:387-407.

[127] De Geest V, De Keulenaere B, De Mey J, Meers E. Voortgangsrapport 2016 - Anaerobe vergisting in Vlaanderen. Kortrijk: Biogas-E; 2016.

[128] De Meyer A, Cattrysse D, Van Orshoven J. A generic mathematical model to optimise strategic and tactical decisions in biomass-based supply chains (OPTIMASS). Eur J Oper Res. 2015;245:247-64.

[129] VCM. VCM - enqûete operationele stand van zaken mestverwerking in Vlaanderen 2016. Brugge: Vlaams Coördinatiecentrum Mestverwerking; 2016. p. 37.

[130] OVAM. Inventarisatie huishoudelijke afvalstoffen 2014. Mechelen: OVAM; 2015. p. 65.

[131] OVAM. Inventarisatie biomassa 2011-2012. Tech rep. Mechelen: OVAM; 2013. p. 90. 
[132] Tilman D, Socolow R, Foley JA, Hill J, Larson E, Lynd L, et al. Beneficial Biofuels-The Food, Energy, and Environment Trilemma. Science. 2009;325:270-1.

[133] Cardinale BJ, Duffy JE, Gonzalez A, Hooper DU, Perrings C, Venail P, et al. Biodiversity loss and its impact on humanity. Nature. 2012;486:59-67.

[134] Costanza R, de Groot R, Sutton P, van der Ploeg S, Anderson SJ, Kubiszewski I, et al. Changes in the global value of ecosystem services. Global Environmental Change. 2014;26:152-8. [135] EEA. The impacts of invasive alien species in Europe. Copenhagen: EEA; 2012. p. 114.

[136] Essl F, Dullinger S, Rabitsch W, Hulme PE, Hulber K, Jarosik V, et al. Socioeconomic legacy yields an invasion debt. Proc Natl Acad Sci U S A. 2011;108:203-7.

[137] Tzoulas K, Korpela K, Venn S, Yli-Pelkonen V, Kaźmierczak A, Niemela J, et al. Promoting ecosystem and human health in urban areas using Green Infrastructure: A literature review. Landscape and Urban Planning. 2007;81:167-78.

[138] Foley JA, DeFries R, Asner GP, Barford C, Bonan G, Carpenter SR, et al. Global Consequences of Land Use. Science. 2005;309:570-4.

[139] Maity SK. Opportunities, recent trends and challenges of integrated biorefinery: Part I. Renewable and Sustainable Energy Reviews. 2015;43:1427-45.

[140] De Meyer A, Cattrysse D, Rasinmäki J, Van Orshoven J. Methods to optimise the design and management of biomass-for-bioenergy supply chains: A review. Renewable and Sustainable Energy Reviews. 2014;31:657-70.

[141] Hensgen F, Buhle L, Donnison I, Heinsoo K, Wachendorf M. Energetic conversion of European semi-natural grassland silages through the integrated generation of solid fuel and biogas from biomass: Energy yields and the fate of organic compounds. Bioresour Technol. 2014;154:192200.

[142] Nicholson M, Biegler T, Brook BW. How carbon pricing changes the relative competitiveness of low-carbon baseload generating technologies. Energy. 2011;36:305-13.

[143] Kalkuhl M, Edenhofer O, Lessmann K. Renewable energy subsidies: Second-best policy or fatal aberration for mitigation? Resource and Energy Economics. 2013;35:217-34.

[144] Steffen W, Richardson K, Rockström J, Cornell SE, Fetzer I, Bennett EM, et al. Planetary boundaries: Guiding human development on a changing planet. Science. 2015;347.

[145] Cherubini F. The biorefinery concept: Using biomass instead of oil for producing energy and chemicals. Energy Conversion and Management. 2010;51:1412-21.

[146] Menon V, Rao M. Trends in bioconversion of lignocellulose: Biofuels, platform chemicals \&amp; biorefinery concept. Progress in Energy and Combustion Science. 2012;38:522-50. 